F. Reprod. Fert. (1970) 22, 77-82

\title{
OCCURRENCE OF AMYLO-1,6-GLUCOSIDASE IN HUMAN SEMINAL PLASMA: ITS PROPERTIES AND SIGNIFICANCE IN SPERM METABOLISM
}

\author{
A. R. SHETH, K. P. GUNAGA AND SHANTA S. RAO \\ Reproductive Physiology Unit (ICMR), \\ Seth G. S. Medical College, Parel, Bombay 12, India
}

(Received 9th April 1969)

\begin{abstract}
Summary. The amylo-1,6-glucosidase activity of human seminal plasma was studied using its specific substrate, $\alpha$-glucosyl Schardinger dextrin. The enzyme activity of semen is predominantly associated with the seminal plasma and proceeds at maximum velocity at $\mathrm{pH} 5 \cdot 8$ to $6 \cdot 0$. The secretions of seminal vesicles and testis seem to contribute most of the enzyme activity to the seminal plasma. Amylo-1,6-glucosidase activity is significantly lower in azoospermic samples as compared to those with a good sperm count.
\end{abstract}

\section{INTRODUCTION}

Human seminal plasma has been shown to contain amylase (Karassik, 1927) and maltase (Sheth \& Rao, 1962a, b). Both these enzymes are known to be involved in glycogen metabolism. Amylo-1,6-glucosidase has been shown to play an important rôle in glycogen degradation. It was, therefore, of interest to find out whether amylo-1,6-glucosidase was present in human semen and whether the level of the enzyme is of metabolic or pathological significance.

\section{MATERIALS AND METHODS}

Semen samples were obtained from fertile donors and from persons referred to our laboratory by the infertility clinic of the K.E.M. Hospital. The seminal plasma was separated from spermatozoa by centrifuging the semen at $300 \mathrm{~g}$ for $30 \mathrm{~min}$. The plasma was stored at $-18^{\circ} \mathrm{C}$ and used when required.

Amylo-1,6-glucosidase activity was estimated according to the method of Taylor \& Whelan (1966). The substrate, Schardinger $\alpha$-dextrin to which an $\alpha$-glucose unit is attached in 1,6-linkage, was kindly made available by $\mathrm{Dr}$ W. J. Whelan (U.S.A.). It has been demonstrated that amylo-1,6-glucosidase degrades the substrate to form glucose and Schardinger $\alpha$-dextrin. Amylo1,6-glucosidase activity of semen was assayed by measuring glucose production using the glucose oxidase method as described previously (Gunaga, Sheth \& 
Rao, 1967). The enzyme activity was expressed as $\mathrm{mg}$ of glucose liberated in $30 \mathrm{~min}$ at $37^{\circ} \mathrm{C}$ per $\mathrm{ml}$ of semen.

The fructose content of seminal plasma was assayed according to the paper chromatography method of Sheth \& Rao (1959).

\section{RESULTS}

Localization of amylo-1,6-glucosidase in the semen

Results depicted in Table 1 indicate that the enzyme activity was localized

TABLE 1

AMYLO-1,6-GLUCOSIDASE LOCALIZATION IN

HUMAN SEMEN

\begin{tabular}{c|c|c|c}
\hline $\begin{array}{c}\text { Sample } \\
\text { no. }\end{array}$ & $\begin{array}{c}\text { Whole } \\
\text { semen }\end{array}$ & $\begin{array}{c}\text { Sperm } \\
\text { suspension }\end{array}$ & $\begin{array}{c}\text { Seminal } \\
\text { plasma }\end{array}$ \\
\hline 1 & $7 \cdot 7$ & $3 \cdot 5$ & $7 \cdot 4$ \\
2 & $36 \cdot 7$ & $5 \cdot 2$ & $36 \cdot 8$ \\
3 & $9 \cdot 5$ & $2 \cdot 1$ & $9 \cdot 5$ \\
4 & $19 \cdot 3$ & $4 \cdot 2$ & $20 \cdot 0$ \\
\hline
\end{tabular}

The enzyme activity is expressed as $\mathrm{mg}$ of glucose liberated in $30 \mathrm{~min}$ at $37^{\circ} \mathrm{C}$ per $\mathrm{ml}$ of semen.

in the seminal plasma. Spermatozoa washed twice with normal saline exhibited low amylo-1,6-glucosidase activity. These results are similar to the observation, that the maltase activity of human semen is contributed predominantly by seminal plasma (Sheth \& Rao, 1962a). Enzyme activity of the sperm suspension may be partly derived from the seminal plasma still present in the suspension fluid.

Properties of seminal amylo-1,6-glucosidase

Results, as can be observed from Text-figs. 1, 2 and 3, indicated that the reaction velocity of seminal amylo-1,6-glucosidase was a function of time, $\mathrm{pH}$ and enzyme concentration. The reaction proceeded at maximum velocity at pH $5 \cdot 8$ to $6 \cdot 0$. The amount of glucose formed was proportional to the enzyme concentration. The enzyme activity progressively diminished on heating the seminal plasma above $40^{\circ} \mathrm{C}$ (Table 2).

\section{Buffer}

Experiments were performed to find out whether the constituents of the buffer used would influence the $\mathrm{pH}$ activity curve. Using a citrate-phosphate buffer, a single peak was obtained with an optimum activity around $\mathrm{pH} 6 \cdot 0$. A similar curve was obtained with only citrate in the buffer (Text-fig. 2).

The influence of buffers of different ionic strengths on the enzyme activity was also investigated. No change could be observed in the activity when the ionic strength of the buffer ranged between 0.05 and $0.2 \mathrm{M}$.

Amylo-1,6-glucosidase activity in relation to spermatozoa per $m l$, motility and volume

The enzyme activity of human semen was studied in relation to percentage 


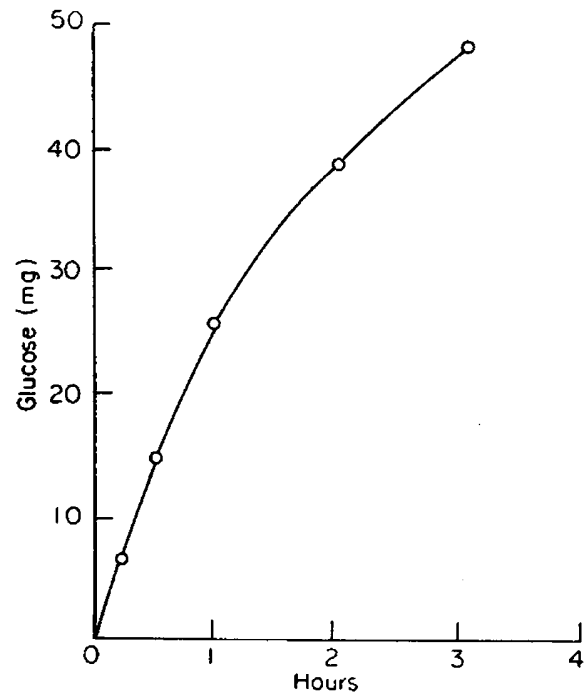

TExr-Fig. 1. Effect of incubation time on the amylo-1,6-glucosidase activity. The digestion mixture contained $0.08 \mathrm{ml}$ seminal plasma, $0.02 \mathrm{ml}$ of substrate $(0.85 \mathrm{mg}$ of dextrin mixture) and $0.1 \mathrm{ml}$ of $0.1 \mathrm{M}$-citrate- $0.2 \mathrm{M}$-phosphate buffer $\mathrm{pH} 5.8$.

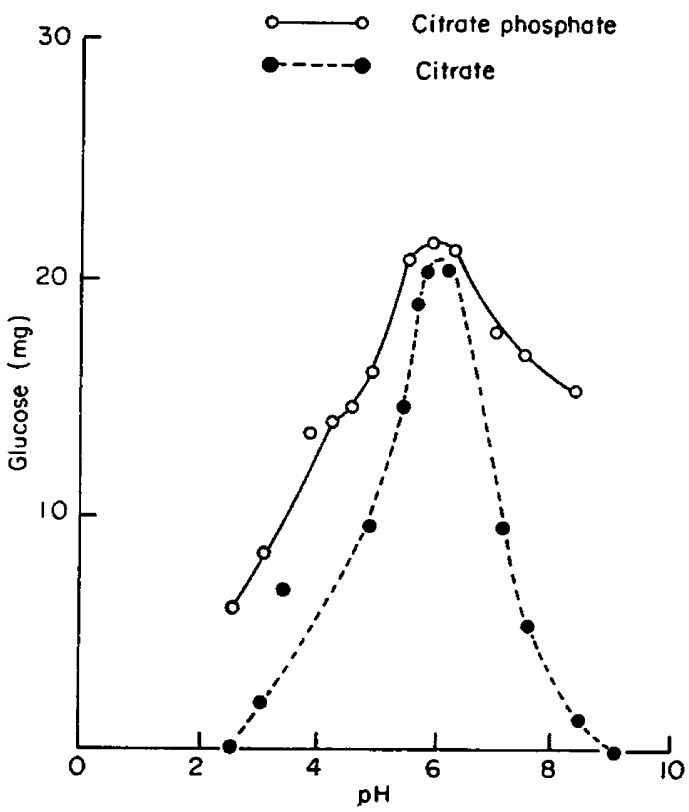

TexT-FIG. 2. Effect of pH on the amylo-1,6-glucosidase activity. The digestion mixture contained, $0.08 \mathrm{ml}$ seminal plasma (diluted with buffer to an appropriate protein concentration), $0.02 \mathrm{ml}$ of substrate $(0.85 \mathrm{mg}$ of dextrin mixture) and $0.1 \mathrm{ml}$ of $0.1 \mathrm{M}$-citrate- $0.2 \mathrm{M}$ phosphate or $0.1 \mathrm{~s}$-citrate buffer of desired $\mathrm{pH}$. Incubated at $37^{\circ} \mathrm{C}$ for $30 \mathrm{~min}$. 
motility, spermatozoa per $\mathrm{ml}$ and volume. In the twenty-three samples studied, the average value of glucose formed was found to be within a range of 3.4 to $68.6 \mathrm{mg} / \mathrm{ml}$ of semen, mean value being $21.4 \mathrm{mg} / \mathrm{ml}$ of semen. Amylo-1,6glucosidase activity was significantly lower in azoospermic samples as compared to those with a good sperm count (Table 3). No correlation was observed

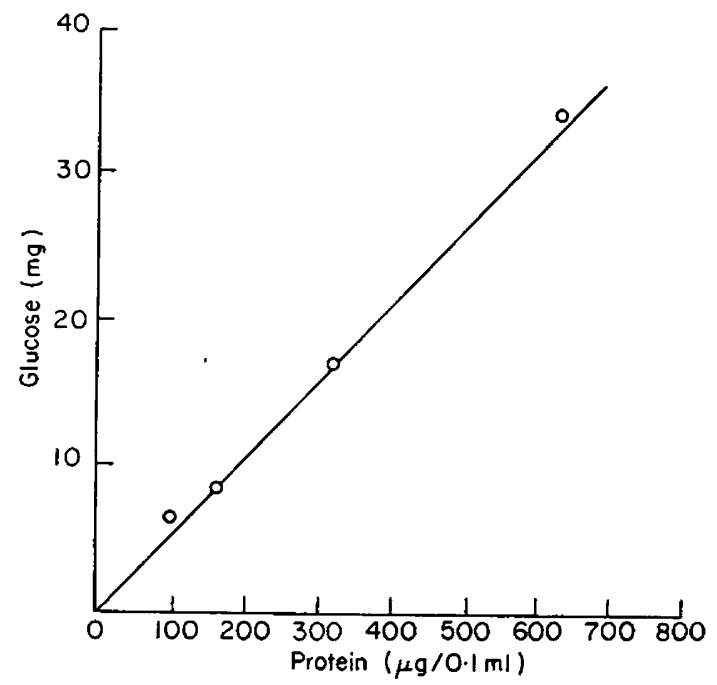

TEXT-FIG. 3. Effect of enzyme concentration on the reaction velocity. The digestion mixture contained $0.08 \mathrm{ml}$ seminal plasma, $0.02 \mathrm{ml}$ of substrate $(0.85 \mathrm{mg}$ of dextrin mixture) and $0.1 \mathrm{ml}$ of $0.1 \mathrm{M}$-citrate-0.2M-phosphate buffer $\mathrm{pH} 5.8$. Incubated at $37^{\circ} \mathrm{C}$ for $30 \mathrm{~min}$.

TABLE 2

HEAT INAGTIVATION OF AMYLO-1,6-GLUCOSIDASE

\begin{tabular}{c|c}
\hline $\begin{array}{c}\text { Temperature } \\
\left({ }^{\circ} \mathrm{C}\right)\end{array}$ & $\begin{array}{c}\% \text { of original } \\
\text { activity }\end{array}$ \\
\hline 30 & 100 \\
37 & 100 \\
50 & $40 \cdot 2$ \\
60 & $\mathrm{3} \cdot 7$ \\
70 and above & $\mathrm{Nil}$ \\
\hline
\end{tabular}

between the enzyme activity and percentage motility or volume of the semen sample.

\section{Source of seminal amylo-1,6-glucosidase}

It was of interest to find out whether the prostate, seminal vesicle or testis is the source of the enzyme in seminal plasma. Samples of split-ejaculates were obtained from two individuals. It is known that the first portion of the ejaculate consists mostly of prostatic secretion. This is based on the absence of fructose in this portion of the ejaculate. It was possible to obtain three samples of prostatic secretion. The second portion of the split ejaculate consists chiefly of seminal vesicular secretion. This is indicated by the presence of fructose in it (Harvey, 1957). The results, as can be seen from Table 4, indicate that the 
major part of the seminal amylo-1,6-glucosidase is contributed by the seminal vesicles and testes. The prostate secretion is unlikely to contribute significant amounts of the enzyme to the semen.

TABLE 3

AMYLO-1,6-GLUGOSIDASE IN RELATION TO SEMEN QUALITY

\begin{tabular}{l|c|c}
\hline \multicolumn{1}{c|}{ Type } & $\begin{array}{c}\text { No. of } \\
\text { samples }\end{array}$ & $\begin{array}{c}\text { Amylo-1,6-glucosidase } \\
\text { per ejaculate } \pm \text { S.E. }\end{array}$ \\
\hline $\begin{array}{l}\text { 1. Azoospermic } \\
\text { 2. Oligospermic: }\end{array}$ & 7 & $11 \cdot 83 \pm 3 \cdot 2$ \\
$\begin{array}{l}\text { Sperm count less } \\
\text { than 30 million/ml }\end{array}$ & 6 & $17 \cdot 97 \pm 6 \cdot 3$ \\
3. Normospermic: \\
$\begin{array}{l}\text { Sperm count more } \\
\text { than 30 million/ml }\end{array}$ & 10 & $30 \cdot 17 \pm 6 \cdot 01$ \\
\hline
\end{tabular}

Between Groups 1 and $2 P<0.3$ not significant.

Between Groups 2 and $3 P<0.2$ not significant.

Between Groups 1 and $30.02<P<0.05$ significant.

The enzyme activity is expressed as $\mathrm{mg}$ of glucose liberated in $30 \mathrm{~min}$ at $37^{\circ} \mathrm{C}$ per ml of semen.

TABLE 4

FRUCTOSE VALUES AND AMYLO-1,6-GLUCOSIDASE ACTIVITY OF PROSTATIC SEGRETION AND SEMINAL SPLIT EJAGULATES

\begin{tabular}{|c|c|c|c|c|c|c|}
\hline Secretions & Samples & $\begin{array}{l}\text { Volume } \\
(m l)\end{array}$ & $\begin{array}{l}\text { Sperm count } \\
(\text { million } / m l)\end{array}$ & $\underset{(\%)}{\text { Motility }}$ & $\begin{array}{c}\text { Fructose } \\
(\mathrm{mg} / 100 \mathrm{ml})\end{array}$ & $\begin{array}{c}\text { Amylo-1,6-glucosidase } \\
\text { activity }\end{array}$ \\
\hline Prostatic secretion & Mean of 3 & - & - & - & Nil & $6 \cdot 94$ \\
\hline $\begin{array}{l}\text { First portion of } \\
\text { split ejaculate } \\
\text { (mostly prostatic } \\
\text { secretion) }\end{array}$ & $\begin{array}{l}\text { Sample A } \\
\text { Sample B }\end{array}$ & $\begin{array}{l}0.5 \\
0.6\end{array}$ & $\begin{array}{l}35 \\
50\end{array}$ & $\begin{array}{l}55 \\
60\end{array}$ & $\begin{array}{l}33 \cdot 3 \\
24 \cdot 8\end{array}$ & $\begin{array}{r}7 \cdot 64 \\
10 \cdot 41\end{array}$ \\
\hline $\begin{array}{l}\text { Second portion of } \\
\text { split ejaculate } \\
\text { (mostly seminal } \\
\text { vesicular secretion) }\end{array}$ & $\begin{array}{l}\text { Sample A } \\
\text { Sample B }\end{array}$ & $\begin{array}{l}1 \cdot 2 \\
1 \cdot 5\end{array}$ & $\begin{array}{l}115 \\
110\end{array}$ & $\begin{array}{l}65 \\
65\end{array}$ & $\begin{array}{l}300 \cdot 0 \\
224 \cdot 4\end{array}$ & $\begin{array}{l}32 \cdot 63 \\
25 \cdot 69\end{array}$ \\
\hline
\end{tabular}

The enzyme activity is expressed as $\mathrm{mg}$ of glucose liberated in $30 \mathrm{~min}$ at $37^{\circ} \mathrm{C} \mathrm{per} \mathrm{ml}$ of semen.

\section{DISCUSSION}

It is well known that the degradation of glycogen can be effected by any of the following three processes: (a) phosphorylysis by the enzyme phosphorylase; (b) de-branching by transferase and amylo-1,6-glucosidase; (c) hydrolysis by amylase and maltase. Human semen has been shown to contain amylase and maltase in significant amounts. The present investigation has demonstrated the presence of amylo-1,6-glucosidase in human semen. Further, it was observed that the level of the enzyme activity was significantly higher in samples with a good sperm count than in azoospermic and oligospermic samples. The occurrence of all glycogen-degrading enzymes in the semen indicates that glycogen which is present in the male and female tract could provide a substrate for the metabolism of spermatozoa. 
Amylo-1,6-glucosidase of human semen was found to have optimum activity at $\mathrm{pH} 5.8$ to 6.0 . This optimum is similar to that reported by Taylor \& Whelan (1968) for amylo-1,6-glucosidase of rabbit muscle, but considerable disagreement exists as to the true optimum $\mathrm{pH}$ of the enzyme as measured with different substrates and by different methods. When dextrin was used as a substrate, the $\mathrm{pH}$ optimum was anywhere from 5.0 to $\mathbf{7 \cdot 4}$ for the rabbit muscle enzyme (Larner \& Schliselfeld, 1956). Taylor \& Whelan (1968) have reported that the type of buffer used also influences the shape of the $\mathrm{pH}$ activity curves. These workers reported that, in a buffer containing citrate and phosphate, or only phosphate, the enzyme gave a single peak with an optimum at $\mathrm{pH} 6.0$ but, when a buffer containing only citrate was used, a second peak became evident with its mode at $\mathrm{pH} \mathrm{7.6}$. They concluded that there were either two enzymes, or one enzyme with double $\mathrm{pH}$ optima, in their material. The present data demonstrate that, irrespective of the type of buffer used, a single peak having an optimum activity at $\mathrm{pH} 5.8$ to 6.0 was observed for the enzyme in human semen.

The activity of seminal amylo-1,6-glucosidase was nearly destroyed when it was heated for $30 \mathrm{~min}$ at temperatures above $60^{\circ} \mathrm{C}$, whereas seminal maltase activity was relatively stable to heating at $60^{\circ} \mathrm{C}$. Only $75 \%$ of the activity was destroyed at this temperature (Sheth \& Rao, 1962a).

The results of the present investigations have revealed that the amylo-1,6glucosidase present in human semen was mostly contributed by the seminal vesicular and testicular secretions. The secretions of the prostatic gland and the first portion of a split ejaculate exhibited very low enzyme activity. It was shown earlier by us that seminal maltase, another enzyme which is responsible for the glycogen degradation, was mainly contributed by the prostate.

Recent studies have indicated that both amylo-1,6-glucosidase and maltase activities of human semen increase with androgen therapy (Gunaga, Sheth, Rao \& Pardanani, 1969).

\section{REFERENCES}

GUNAGA, K. P., SHeth, A. R. \& RAO, S. S. (1967) Maltase activity in the accessory reproductive organs of rats and mice. Indian F. exp. Biol. 5, 141.

Gunaga, K. P., Sheth, A. R., Rao, S. S. \& Pardanani, D. S. (1969) A preliminary study on the effects of testosterone on some of the constituents of human seminal plasma. Indian J. med. Res. (in press).

HaRvey, C. (1957) The use of partitional ejaculates in investigating the role of accessory secretions in human semen. Proc. Soc. Study Fert. 8, 3.

Karassik, W. M. (1927) Über die fermentativen Eigenschaften des Prostatesekrets im zusammenhang mit der Bedentung der Prostata im der Spermatozoenbewegung. Z. ges. exp. Med. 53, 734.

LARner, J. \& Schliselfeld, L. H. (1956) Biochim. biophys. Acta, 20, 53, as quoted by Taylor, P. M. \& Whelan, W. J. (1968) see below.

Sheth, A. R. \& RAO, S. S. (1959) Fructose and fructolysis in human semen determined chromatographically. Experientia, 15, 314.

Sheth, A. R. \& RAo, S. (1962a) Maltase activity in human semen. Experientia, 18, 370.

Sheth, A. R. \& RAO, S. S. (1962b) Purification and properties of human seminal maltase. F. Reprod. Fert. 4, 267.

TAYLOR, P. M. \& WhELAN, W.J. (1966) A new substrate for the detection of amylo-1,6-glucosidase and its application to the study of glycogen storage disease type III. Archs Biochem. Biophys. 113, 500.

TAylor, P. M. \& Whelan, W. J. (1968) Rabbit muscle amylo-1,6-glucosidase: Properties and evidence of heterogeneity. In: Control of glycogen metabolism. Proc. IVth meeting of Fedn European Biochemical Societies, Universitetsforlaget, Oslo, p. 101. Ed. W. J. Whelan. Academic Press, London. 